boots rated to $-65^{\circ} \mathrm{C}$ and Wind River apparel including a down parka. The proceeds go to the library fund at CNSC. After dinner we were entertrined by Rick Riewe, who contrasted strategies of Eskimo living in the most southerly community (Eskimo Point) with those living in the most northerly community (Griese Fiord).

On Saturday, we delayed the start of talks until 1:00 pm to allow for the 'train gang' to arrive and settle in at the CNSC. In all, about $30-45$ people attended throughout the weekend, depending on the event. In the middle of a full arctic blizzard (with temperature and windspeed off their respective scales) on Sunday alfternoon the valiant NRC staff cleared the $18 \mathrm{~km}$ road to Churchill and we bussed into the town movie theatre for a public showing of Inuit (Eskimo) fashions by Jill Oakes. We also toured the 'Complex' as the 'Modern Man' aspect of the 'Man in Winter' theme of the Workshop. After an early return to the CNSC, the question arose: How many blocks did Buster Welch use in making his igloo over the lunch hour? And while the igloo was within $100 \mathrm{~m}$ of the building, it took several expeditions to find all of the outfits that were looking for the igloo!

The workshop focused on igloo building on Monday, with instruction and much humour provided by Buster Welch and Rick Riewe. However, we did manage to complete 5 more passable igloos by sundown. Johan Tast was surprised to find that the yellow glow at the foot of the igloo in the morning was not the sunrise but was in fact yellow snow of obvious origin. And although vehemently denied by G.P. Kershaw, certain vigilantes aided by the local Arctic Fox population avenged Johan on the subsequent evening. On Tuesday, we were visited by a joint flock (herd?) of Willow and Rock Ptarmigan
(Lagopus lagopus and L. mutus, respectively) on our way off to the 'Walk Across the Continental Treeline'. We found considerable evidence of Snowshoe Hares (Lepus americanus) that were sleeping under Larch (Larix laricina) trees in the forest. We were hosted at Parks Canada by a notable Cree Interpreter who gave us an overview of 'Historic Man in Winter', highlighting our visit with the story of the Polar Bear in the beer hall. We were then hosted by the entire high-school where we took part in a panel discussion on various topics from global change to fish pollutants.

These are just a few of the many events and highlights of the first winter symposium. I say 'first' because I think there was unanimous recommendation for a second symposium at Churchill during 1992. Most people commented that the first event was not long enough and that the strong community support was very impressive. There are those participants who felt that the 1992 could not possibly top the 1990 Symposium. However, Dennis Macknak, Director of CNSC, has taken up the challenge. We already have a commitment for a genuine Finnish sauna to be built by Johan Tast for the next meeting, and a sub-marine demonstration by Buster Welch has been threatened as well. There are also plans in the works to allow people to make their own skin clothing which could be used while building their own igloo to sleep in.

PETER A. SCOTT, Symposium Chairman
Churchill Northern Studies Centre (CNSC)
PO Box 610
Churchill
Manitoba ROB OEO
Canada.

\title{
Ecological Research at the Indian Institute of Science: An Overview
}

The Indian Institute of Science, established in 1909 under the British, is located in Bangalore in the State of Karnataka. Currently there are over forty departments/centres on the campus of 372 acres (150.6 ha). Most pertinent for readers of Environmental Conservation is the Centre for Ecological Sciences in the Faculty of Life Sciences, which was initiated in 1982 primarily for conducting field research. This Centre is the first of its kind in India and is supported by the Department of Environment and Forests of the Government of India. Convened by Professor Madhav Gadgil since 1984, this Centre has been actively conducting both fundamental and applied research in various fields of ecology - such as biological species diversity, large-mammal ecology, insect behaviour and sociobiology, human ecology, ecodevelopment, and mathematical modelling.

Field research on animal and plant communities including the flowering plants, insects, amphibians, birds, and larger mammals - in the Western Ghats has been the primary interest of this Centre. The impacts of vegetation changes and human intervention on these natural communities have been looked at intensively, and conservation plans have been prescribed by the Centre. The role that Man plays in shaping the individual ecosystems - and hence the entire ecocomplex - by his dependence on the available primary resources, has been the focus in human ecology.

Fundamental questions on the evolution of eusociality and theories such as kin selection, are being answered in the well-established insect behaviour and sociobiology laboratory. The Centre maintains a permanent 50hectares' plot in the Western Ghats at Mudumalai (southwest of Bangalore), where mammal interactions with vegetation and the dynamics of tropical forests are being continuously monitored. Ecodevelopment emphasizes the need for Man to improve his management of biological communities through revegetation and more prudent use than is currently practised of fuel, fodder, and other raw materials extracted from the natural ecosystems of the Western Ghats. Simulations and mathematical models in all the abovementioned fields are simultaneously being dealt with in this Centre.

Since 1985, doctoral students (1-3 per year) have been offered fellowships to work on problems including community ecology of birds, insect behaviour and sociobiology, plant phenology, human ecology, ecological history of landscapes, parasite-host relationships in large mammals, and ecosystem management. The centre has three well-equipped field stations in Sirsi, Kumta (both in northern Karnataka), and Mudumalai (Tamilnadu), to facilitate field research in the Western Ghats. The Centre entertains Indian as well as foreign visitors.

The Centre trains personnel for field research and ecosystem management through direct field courses and workshops. One of the most significant workshops conducted at the Indian Institute of Science by the Centre for Ecological Sciences was the First Asian School on Conservation Biology, held in December 1987. The event 
brought together 48 scientists and resource managers from all over Asia - including Afghanistan, Pakistan, India, Nepal, Sri Lanka, Thailand, Bangladesh, Malaysia, Indonesia, China, and Japan. An outcome of that initiative has been the informal Asian Conservation Network which functions with its secretariat at the Centre.

Besides the above major training programmes and pertinent activities there have been several ecodeve- lopment and Nature camps conducted by the Centre in the rural areas of the Western Ghats.

\section{R.J. RANJIT DANIELS Centre for Ecological Sciences Indian Institute of Science Bangalore 560012 India.}

\section{USSR Becomes IUCN's Fifty-fourth Nation-state Member}

The Soviet Union became IUCN's 54th state member in April of this year*, and the first from the eastern European region. Approval for membership was sought and obtained from all fifteen Republics of the USSR - a notable achievement in a time of ethnic tension and nationalist sentiment, demonstrating once more that concern for the environment has the power to bring people together to achieve shared goals. It is, however, not so surprising in a country where opinion polls consistently show that the environment is a major source of public concern.

In spite of media concentration on the dark side of the Soviet environment, its vast region contains many species and habitats that have all but disappeared from western Europe, and wildlands that are hard to find anywhere else. IUCN hopes to be able to cooperate with its new State

* A notice at the time indicated that 'The Soviet decision was communicated to the Union by Dr Vladimir Sakharov, Head of International Relations of the Ministry for Nature Conservation and Environmmental Protection of the USSR, [when he was] attending a meeting in Geneva ... of the United Nations Economic Commission for Europe. The United States also [only] recently joined the World Conservation Union as a state member.' - Ed. member in formulating and implementing policies and strategies that conserve the rich natural heritage while at the same time allowing and even encouraging non-destructive economic development.

An IUCN National Committee will be formed in the USSR, representing all its Republics and the scientific and conservation community, and will embark on development of a joint programme with IUCN. The first meeting of the Committee is scheduled for the autumn of 1991. A Secretariat to service the Committee and coordinate IUCN-Soviet activities will be established in the AllUnion Institute for Nature Protection and Reserves, Moscow, USSR.

Meanwhile, the IUCN East European Programme and its partners in the Soviet Union have not been idle, and the third and last volume of national environmental status reports, which covers the European USSR, is in press and will be published shortly.

\section{ElizabeTH Hopkins, Co-director \\ East European Programme \\ The World Conservation Union (IUCN) \\ Avenue du Mont-Blanc \\ 1196 Gland, Switzerland.}

\section{Leading Champions of Wildlife Lost to Dastardly Acts}

With, surely, the rest of the civilized world, the International Society of Naturalists (INSONA) deeply mourns the brutal assassination, under the most extraordinarily tragic circumstances, of the former Prime Minister and former Chairman of the Indian Board for Wildlife, Shri Rajiv Gandhi, on 21 May 1991. It is a sad loss indeed to the environmental and wildlife conservation movement in the Indian subcontinent.

Shri Rajiv Gandhi helped in our crusade to save the habitat of Antelope cervicapra - the endangered Blackbuck (Gaekwad \& Oza, 1988). Earlier, in our endeavours to save the Kashmir Deer (Cervus elaphus hanglu), popularly known as the Hangul, from the brink of extinction, the late Prime Minister Smt. Indira Gandhi, as the then Chairperson of the Indian Board for Wildlife had graciously extended support (Oza, 1987). She also helped in my attempts to have the Silent Valley recognized as a World Heritage Site (Oza, 1981; Venkateswaran \& Polunin, 1984).

India achieved several conservation successes during the time when Indira and then Rajiv Gandhi served as the Prime Ministers of the world's second most populous country. Nature lovers and conservationists described that period as 'now or never' for serving the cause of wildlife conservation. So altogether it is a multiply shocking trajedy that earlier the Mother, and then recently the Son, who both rendered paramount services to save Indian wildlife, have been done to death in the most tragic and barbaric circumstances, when the Nation needed their services the most.

Smt. Indira Gandhi's tragic end came on 31 October 1984, in New Delhi, in her Prime Minister's residence at the treacherous hands of her own armed bodyguards. Campaigning intensively and extensively during the 1991 Indian election, her only surviving Son, Shri Rajiv Gandhi, travelled almost everywhere freely, mixed among the masses fearlessly, even sweeping aside the security shields, warnings, and obstacles.

He lost his precious life to brutal, dare-devil assassination on 21 May 1991 in Sriperumbudur (Kancheepuram taluk, Chengai-Anna district, on the Madras-Banglore highway). The latest intelligence reports which appeared in the Press reveal that the disastrous end could have occurred elsewhere during the campaign if the assassin(s) failed to strike the death-blow near Madras.

Shri Rajiv Gandhi was annihilated, on that fateful night in Sriperumbudur, by the suicide mission of the 'belt-bomb' woman, who, it is believed, waited to garland him. Eye-witnesses narrated that she could have bent forward with an intention to touch his feet - as a mark of respect - and consequently could have activated a timer, triggering the explosion. The woman, it is reported, had tied the 'live bomb' belt to her back. 